\title{
The Development of Online-Based Eka Lopen Program (Evaluation Of Academic Competence In Management Education)
}

\author{
Eka Prihatin \\ Faculty of Education \\ Indonesia University of Education \\ ekaprihatin@upi.edu
}

\begin{abstract}
The purpose of this paper was to develop a program called EKA LOPEN, which was an online program, used to evaluate academic competence. This research was conducted on the timeframe of less than one year using research and development design that followed the steps of study literature regarding needs analysis of EKA LOPEN, development of EKA LOPEN, as well as its testing and evaluation. This study resulted on an application or program used to help facilitating learning evaluation process that can save various types of sources in its implementation. Besides providing a base too understand the EKA LOPEN program, this study is also contributing to the literature of learning evaluation model used to assess students' academic competency. This program can assist implementation of the UAS (final term exam) faster, more accurate and inexpensive manner, which makes the development of this program a top priority in efforts of building the character of education through eliminating the opportunity for the students to cooperate or cheating on the test.
\end{abstract}

Keywords-EKA LOPEN program; online exam; evaluation of academic competence

\section{INTRODUCTION}

Learning evaluation is one of the most important activities in the learning process. Where the results obtained, besides being able to measure students' ability, it is also able to be a self-assessment media for educators to evaluate the success of teaching and learning strategies. Based on Standards Education Process stated in Government Regulation No. 19 of 2005 on National Education Standards Article 19 Paragraph 3 and Article 20:

Each educational unit is regulated to plan, implement, assess and supervise the effectiveness and efficiency of learning process...the learning process, to implement it, to assess it of the learning process, learning outcomes assessment, and supervision of the learning process effective and efficient ... it covers syllabus and lesson plan that includes at least the purpose of learning, teaching materials, teaching method, learning resources, and assessment of learning outcomes.

Learning outcomes assessment activities undertaken by teachers has meaning as an attempt to gather information about the learning outcomes. Assessment conducted by teachers is a form of responsibility that must be implemented by teacher after or during the learning process. The results of this assessment will be used as an ingredient in the evaluation that would then be used to make decisions about students' learning outcomes (Tucker et al in Gareis, 2007: 20).

Until today, the Indonesian government still focuses the evaluation of learning outcomes into the traditional way both oral and written exams, both in form of essay and multiple-choice questions. But in reality that occurs at Indonesia University of Education, particularly in management of education course, which is one of the subjects of MKDU (additional subjects) organized by the Department of Educational Administration (FIP UPI), the educational management course is a compulsory subject that should be taught in all departments UPI, which contributes to the conduction of UAS (Final Exam) simultaneously on the same days and hours.

Its implementation process becomes very complicated, when the educational management lecturers was relatively smaller in number compared to the classes that should be monitored. At that time, the faculty policy was that the administrative personnel should assist the activity, by which the administrative services were disrupted. Looking at the form of the test, which consisted of closed questions (multiple choices) and open questions, the exam indeed required great human resources, costs and facilities. Therefore, there is a need for a new system in the execution of final exams that can save the source of funds and human resources, which is a learning evaluation program that can be utilized by making use of Internet connection.

The Internet itself has expanded in many fields, including in the field of education. Facilities provided by the Internet are not limited. Today, communication facilities provided by the Internet have enabled online classroom into reality by using a web page text based, electronic mail (e-mail), exchange text or voice directly (Internet Relay Chat), and a variety of interactive multimedia facilities. Thus, the teaching and learning activities can be carried out, both delayed (delayed, such as via e-mail) as well as directly or instant (realtime, for example through the IRC and audio-video conferencing). In addition to the learning process of planning 
and implementation of the learning process, the Internet can also be used to facilitate learning outcomes assessment, and effective and efficient supervision of the learning process, which can be facilitated by the development of EKA LOPEN.

\section{LITERATURE REVIEW}

One of the student management activities that should be done throughout the learning process is evaluating their learning outcomes. This activity is conducted to determine the extent to which the development of learners in certain subjects has referred. According to Suharsimi Arikunto (2009: 24-25) evaluation is data collection activities being conducted in order to measure the extent to which objectives have been achieved, which in its formulation, the evaluation activities should be based on objectives that were formulated. Besides referring to the goal, the evaluation should also refer to or adapt KBM (learning activities) being implemented.

Pophan (1987: 9) argues that evaluation is a series of information used to decide students' learning achievement. Amri, (2013: 217) describes evaluation process as a process of planning, acquiring, and providing needed information to make alternative decisions. Evaluation can be used to check the rate of success of the program with regard to environmental programs and a judgment, whether the activity continues, delayed, improved, institutionalized, accepted, or rejected. These decisions can also serve as indicators in performance assessment at every phase of the evaluation, which can be represented in three categories: low, moderate, and high.

The purpose of learning evaluation for the students is so they can to determine how much the development of cognitive, affective and psychomotor obtained during their education period (Eka Concerned, 2011: 107), while for the institution, learning evaluation can measure the effectiveness of an agency in providing learning experience. Moreover, for the educators, it can represent the effectiveness of teaching strategy the use.

The purpose of assessment in learning are (1) providing feedback for learners to identify the weaknesses and strengths in a particular subject or field, (2) providing feedback for teachers to know the effectiveness of learning activities that he/she conducts, (3) providing information for parents as well as a media for schools to highlight its responsibility in managing the learning activities, (4) as a consideration in giving reward and motivation to students to improve their learning efforts (Ward, 2004: 1).

Learning assessment needs to be done thoroughly and continuously in accordance to what Allen in Praslova (2010: 1) states that the assessment is an ongoing process that is designed to monitor the learning process and improve learning outcomes as well as capture the student's ability.

In practice, the learning assessment in educational management course at Indonesia University of Education implements formative test, both in form of objective and subjective one. The reason for this is to facilitate educators in evaluating the learning process. This test model is perceived to be less effective and efficient with regard to the number of educational resources required. It also requires great amount of budget associated with various types of incentives and fee including the budget for making the printouts. Thus, there is a change to reduce the use of paper as well as participate in eco green campaign. Almost all students UPI use mobile phones as a social media with very high Internet usage. It can be used as media in accessing learning materials. Apart from the digital library, it can also facilitate e learning and e-evaluating through online EKA LOPEN program. The description of EKA LOPEN can be seen as follows:

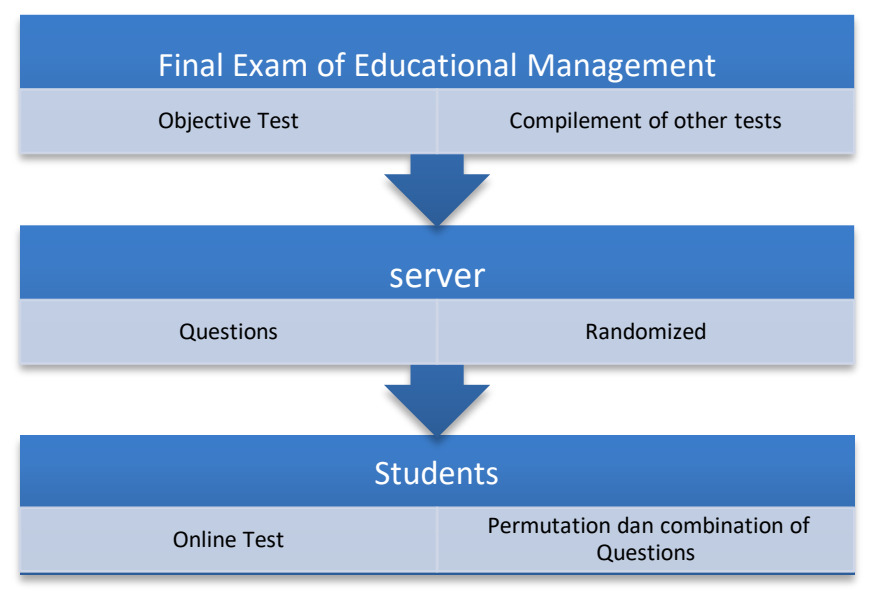

The advantages of this online exam, among others are 1) facilitating easier procedures for learners and educators undertake the exam; 2) reducing the possibility of cheating in the exam; 3) reducing the requirement of high surveillance procedures without affecting the quality of the exam procedures; 4) providing short process of obtaining the scores; 5) suppressing financial requirement up to $90 \%$; 6) Supporting eco green campaign. But there are several disadvantages occur from this online model. They are 1) the Internet speed can affect the speed of learners in completing the exam; 2) The possibility of hacker; 3) The test can only involve objective type of questions.

\section{RESEARCH METHODOLOGY}

The design of this study referred to research and development design related to the development of ICT-based learning evaluation model that was conducted online. The research procedure of this study followed Brog and Gall (1983: 772) in Sugiyono (2004: 353) that included: (1). Conducting preliminary studies, (2) planning, (3) developing the initial product, (4) conducting preliminary field test, (5) revising the main product, (6) conducting field test, (7) revising the 
operational product, (8) conducting operational field test, (9) revising the final product and (10) performing dissemination.

In this study, Brog and Gall's research procedures mentioned above were simplified with regard to the fulfillment of the essence of the steps in the implementation of the study. Operationally, the research procedure was conducted as follows:

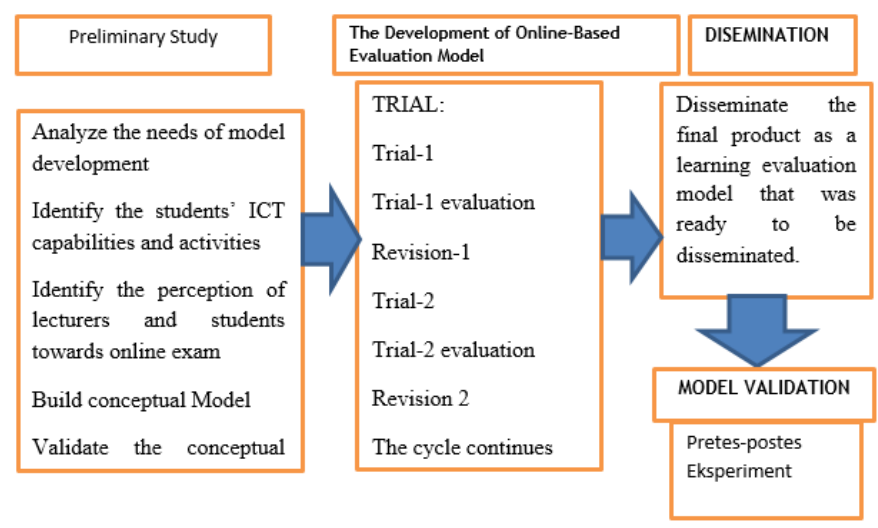

Preliminary studies

a) Analyze the needs of model development

b) Identify the students' ICT capabilities and activities

c) Identify the perception of lecturers and students towards online exam

d) Build conceptual Model

e) Validate the conceptual model

Model field test:

a) Trial-1;

b) Trial-1 evaluation

c) Revision-1

d) Trial-2

e) Trial-2 evaluation

f) Revision 2

g) The cycle continues

Validation Model

Disseminate the final product as a learning evaluation model that was ready to be disseminated.

The development of online-based academic Competence Evaluation Model

1. Pretest-posttest

2. Experiment

Dissemination

The steps in this study were reached through the following steps,

1. Preliminary Study, which contains activities that include:

a. Conduct a literature study by reviewing the literature related to building ICT in the form of making the program according to the model that will be built.

b. Conduct a field survey, which aims to obtain data on the perception of educators and learners related to the implementation of an online exam.
2. Development Model, which contains activities that include:

a. Drafting Products: initial design of on-line test

b. Limited test: testing the early design in one major that follows the lecture of Educational Management

c. Evaluation and Revision of the limited test results

d. Extensive trial: testing the revised model limited to all students who take the course of Educational Management

e. Evaluation and Revision of comprehensive test results.

3. Testing the Model, Using quasi experiment of pretestposttest, the study tested it to two control groups and two experimental groups. The steps are as follows:

a. The groups were not chosen randomly.

b. The groups were given four times pretest in order to get the high level of certainty.

c. The groups were given treatment

d. The groups were given four times post-test in order to get the steady results.

Disseminate the final product as a model of learning evaluation (test on-line), through the following activities:

a. Evaluation of the results of the development of on-line test model

b. Socialization models through:

- Seminar

- Training

- Journal

- Books

c. Implementation of the model

d. Supervision

e. Evaluation

f. Model improvement

Research Outcomes

The outcomes of this study were a computer program that was a permutation of $\mathrm{c}++$ program which automatically randomized exam question, so permutations and combinations of exam question greatly varied along the calculation of its permutations and combinations.

\section{RESULTS AND DISCUSSION}

RESEARCH RESULT

Online exam program called EKA LOPEN (Academic Competence evaluation of Educational management) was designed to enhance the effectiveness and efficiency of educational management final exam, which was carried out simultaneously throughout all education departments at Indonesia University of Education. In the first term of 2016 this exam was taken by 33 education majors with approximately 1320 students, while in second term, there were 2600 participants grouped in 66 majors. Moreover, it involved 221 inspectors consisting of faculty and staff member of the Faculty of Education UPI.

Program EKA LOPEN was designed using online examination system, which consisted of 75 questions prepared by 
administrative officers, and the program was already completed with anti-cooperate or anti-cheat so that through this program, every student received different scrambled order of questions. The aim was to generate good educational value.

The development of the early model was carried out fulfilling online test property, which among others were:

1. The development of on-line web exams, called EKA (Evaluation of Academic Competence)

2. The program to incorporate and replace the question

3. The development of student data to login

4. The development of online test guidance

5. The development of the number of questions, which initially were only 10 questions (became 75 questions)

6 . The development of a synchronization program between questions and answers

7. The development of the ability of randomizing questions

Trial-1, by involving 3rd semester students (30 students) the trial was intended to test the ability of the program in randomizing questions as well as to see the level of perfection of this program. The result was very good, which includes,

a. The succession of EKA web loading process

b. Every student got different question,

c. In a matter of entering the answer, this program could only facilitate 5 point and if there was an answer that was too long then it was cut automatically

d. Students could log in and fill the data themselves

e. Students were able to read and understand the guide to the online test very well

f. The number of questions that could be uploaded to the program was only as many as 5

g. Answers moved randomly along the matched questions

$\mathrm{h}$. The movement of question was in accordance with a permutation

The obstacles are not consistent signals and display when using HP rudimentary. Repair program does is look to HP and look for a location that has with a good signal; it was decided to do an exam in UPINET.

Trial-2, final exam for the course of educational management courses involved 74 students who performed the test at UPINET. The trial results were very satisfactory, with details:

a. Due to the number of examinees, there was an issue related with the Internet speed, it was likely a server problem, so the test could not be carried out simultaneously

b. Questions entering process reached as many as 75 questions

c. Students were able to read and understand the guidance to the online test

d. The number of questions that could be uploaded reached as many as 75 questions

e. Answers moved along with the matched questions

$\mathrm{f}$. The randomization was in accordance with its permutation

g. Once completed, scores appeared immediately

h. Stable signal, so there was not any complain from the students i. Scores of the exam could directly be visible, so that lecturers did not have to correct it manually.

There were several points from this program that were found to need some improvement:

a. Accurate processing time made the program to shut down after the determined range of time, which was perfect for maintaining the perfection of the test.

b. The timetable had been adjusted to the educational schedule, so if it was not on the schedule, the students could not access it. This system was also beneficial in keeping the exam to be held on time.

c. Due to the fact that EKA LOPEN was going to be applied by Educational Administration department, there was a need to refine the platform with an addition of lecturer's page, so the students score could be entered to the right lecturer's page.

d. UPINET could only accommodate 300 students in one test, so that the strategy was grouping the students. Thus, in case there were 1200 students in total, then there would be four groups consisting of 300 students conducting the exam. Moreover, there would be some requirement that the question bank should have at least 1000 questions that could be permutated/ randomized as many models as the admin decided, so despite the grouping strategy, the authenticity of the questions are perfectly preserved.

This development process of EKA LOPEN program will continue to be made in order to get the desired results, which are program refinement and its time limit system.

DISCUSSION

This online-based learning evaluation process using EKA LOPEN is closely related to the quality of ICT being used. Research in this first year has not given satisfactory results so that improvements to it are being submitted for the phase two of study.

Based on the purpose of the 1st, which is improving the quality of customer service education Universitas Pendidikan Indonesia, it gives a positive start, which is based on the observation showed that through the test on-line learners get the ease of implementation of final exams Education Management, it reduces the time in preparing for exams, which usually students looking for a room and wait supervisors brought about, then in the trial they can sit anywhere in the room UPINET using their own laptop and modem or using a computer that has been provided in UPINET. In this experiment the students could sit adjacent to another friend, because the matter in the trial are randomized so that the chances of getting the first question the same 99.9\%. Improved evaluation of on-line services is under observation while almost $89 \%$ expressed a sense of pleasure and satisfaction.

Based on the purpose to 2 that planning learning evaluation programs in the form of on-line test for the course MKDU, by conducting two trials, it was found some deficiencies that must be corrected immediately to Year 2 of them are: 
1. Changing the view of online exam through enhancing various related aspects

2. Designing a time limit ranging from starting the exam until the end

3. Having the time schedule, in order to (a) prevent learners from taking the exam more than once; (B) keep the program from being opened before the schedule $(\mathrm{C})$ only allow the students who are registered to taking the course;(D) only allow the lecturers to examine the score of their students.

4. Giving $\log$ in access to lecturers to examine their registered students through simple log in system or automatic email system.

5. Designing the question bank with at least 1000 questions, which are ready to randomize

6. Additional access points (1:40) and appointed own server for the smooth implementation of the test.

Based on the third objectives, this program promotes the act of preventing global warming by conducting paper-free exam. Thus, the provider does not have to waste hundreds of rim of paper to facilitate this activity.

Based on the forth objective, this program promotes the effectiveness and efficacy of resources in undergoing the evaluation process by reducing several types of costs, including but not limited to testing media like paper for question and answer sheet, exam inspector incentives, preparation of exam rooms, inspector meals allowance. Thus, the mention budgeting can be reappointed to: (a) IT personnel's fee and allowances (300 students: 2 lab personnel). They are only intended to assist learners when experiencing problems related to ICT media, (B) the examination hall (UPINET).

Based on the fifth objective, this program has contributed to the development of learning evaluation model needed by educational administration department. This model is designed to better facilitate, as well as improve students' learning evaluation services.

\section{CONCLUSIONS AND RECOMMENDATIONS}

This study resulted on an application or program used to help facilitating learning evaluation process that can save various types of sources in its implementation, called EKA LOPEN. In the future, this program is expected to be used in a variety of subjects and at every educational level due to its advantages in implementing fast, precise, accurate and cheap learning evaluation model. The program can also build a good character in education by eliminating the opportunity to cooperate and cheat among students when they are undertaking exams.
[1] Amri, Sofan. (2013). Pengembangan Dan Model PembelajaranDalamKurikulum 2013.PrestasiPustakaraya, Jakarta.
[2] Arikunto, Suharsimi. (2009). Dasar- DasarEvaluasiPendidikan.BumiAksara, Jakarta.
[3] Depdiknas. (2005). PeraturanPemerintahRiNomor 19, Tahun 2005, TentangStandarNasionalPendidikan.

[4] Gunadi, R. Andi Ahmad. (2014). EvaluasiPembelajaranAktifKreatifEfektif Dan MenyenangkanDengan Model Context Input Process Product. JurnalllmiahWidya. JurnalIlmiahWidya. Jakarta

[5] Prihatin, Eka; (2011), ManajemenPesertaDidik. Alfabeta, Bandung.

[6] Pophan, James W. (1987). Educational Evaluation. Prentice Hall Inc. New Jersey.

[7] Sastromiharjo, Andoyo. Model PembelajaranKeterampilanBerbahasaBerbasisICT.Upi. Bandung

[8] Sugiyono. (2004). MetodePenelitianAdministrasiPendidikan. Bandung: Alfabeta

[9] Http://Cahpienter-Ilmuku.Blogspot.Com/2011/07/VBehaviorurldefaultvmlo.Html

[10] Http://Hidayatwae.Wordpress.Com/2012/12/17/Permutasi-DanKombinasi-Dalam-Ilmu-Komputer/

[11] Http://Cahpienter-Ilmuku.Blogspot.Com/2011/07/VBehaviorurldefaultvmlo.Html 